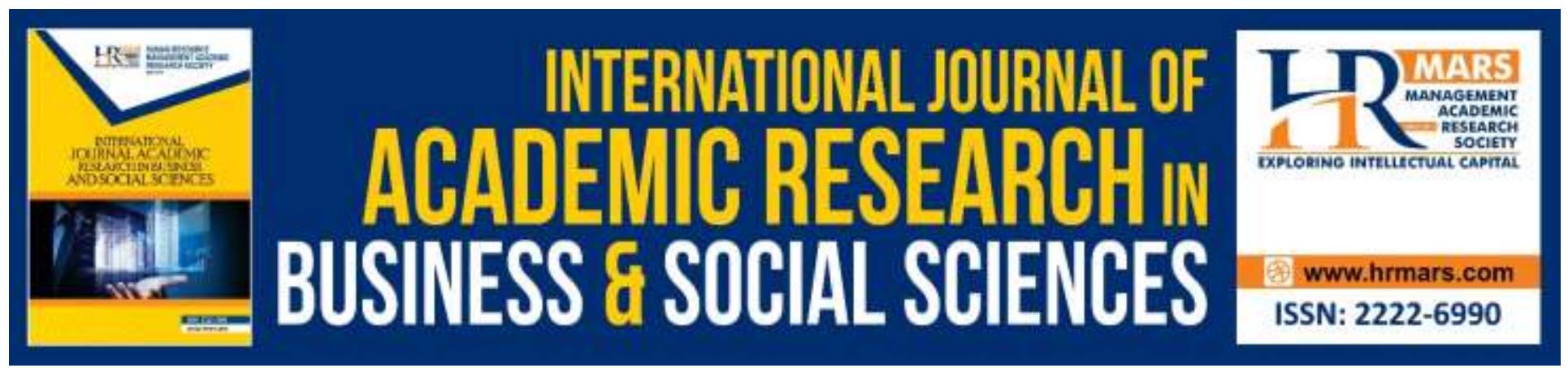

\title{
The Role of Internal Social Responsibility in Achieving Organizational Symmetry
}

Jassim Mohammed Al Jaidah, Abdallah Mishael Obeidat

To Link this Article: http://dx.doi.org/10.6007/IJARBSS/v10-i5/7245

DOI:10.6007/IJARBSS/v10-i5/7245

Received: 24 March 2020, Revised: 20 April 2020, Accepted: 28 April 2020

Published Online: 29 May 2020

In-Text Citation: (Jaidah \& Obeidat, 2020)

To Cite this Article: Jaidah, J. M. Al, \& Obeidat, A. M. (2020). The Role of Internal Social Responsibility in Achieving Organizational Symmetry. International Journal of Academic Research in Business and Social Sciencess, 10(5), 730-752.

Copyright: (c) 2020 The Author(s)

Published by Human Resource Management Academic Research Society (www.hrmars.com)

This article is published under the Creative Commons Attribution (CC BY 4.0) license. Anyone may reproduce, distribute, translate and create derivative works of this article (for both commercial and non-commercial purposes), subject to full attribution to the original publication and authors. The full terms of this license may be seen at: http://creativecommons.org/licences/by/4.0/legalcode

Vol. 10, No. 5, 2020, Pg. 730 - 752

http://hrmars.com/index.php/pages/detail/IJARBSS

JOURNAL HOMEPAGE

Full Terms \& Conditions of access and use can be found at http://hrmars.com/index.php/pages/detail/publication-ethics 


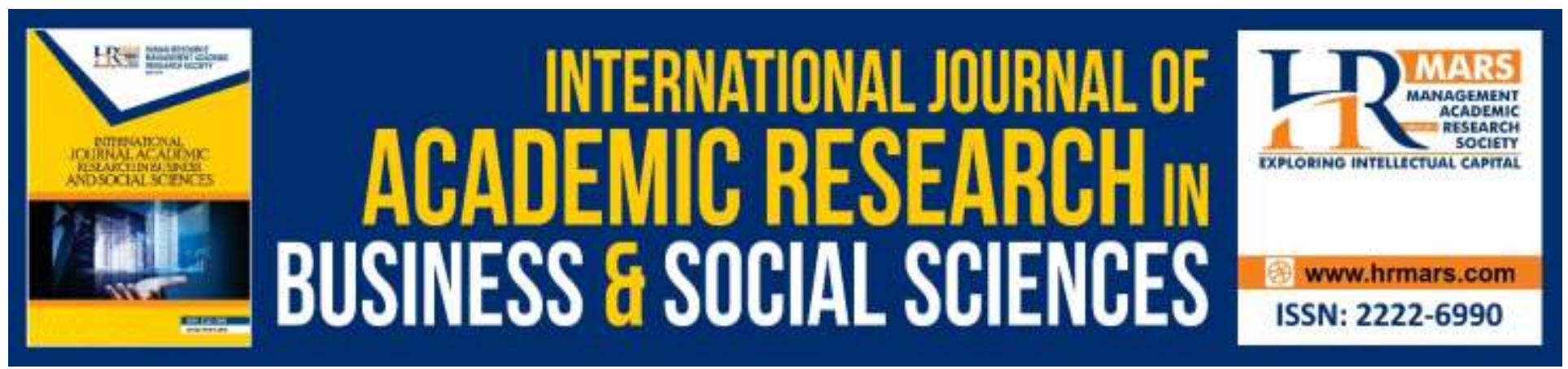

\title{
The Role of Internal Social Responsibility in Achieving Organizational symmetry
}

\author{
Jassim Mohammed Al Jaidah \\ Business Administration Department, Business Collage, Jadara University \\ Email: j.aljaidah@me.com
}

\author{
Dr. Abdallah Mishael Obeidat \\ Assistant Prof, Business Administration Department, Business Collage, Jadara University, Jordan. \\ Email: 29TUaabdullahh2000@hotmail.comU29T \\ Email: aobeidat@jadara.edu.jo
}

\begin{abstract}
This study aimed to identify the role of internal social responsibility in achieving the organizational symmetry of employees in Qatar commercial banks, and to achieve this goal the researcher relied on the descriptive analytical method and designed and distributed the questionnaire to the sample of the study consisting of 372 employees working in Qatar commercial banks, and the number of questionnaires can be analyzed 310 questionnaires. The study found that internal social responsibility has had an impact on organizational symmetry in Qatar commercial banks. The study recommended the need for Qatar commercial banks to adhere to their internal social responsibility and maintain them, because they have a positive impact on the performance of their employees and achieve their objectives, work to meet the needs and requirements of their employees, and increase the amount of material and moral benefits they achieve, which will generate a sense of satisfaction and belonging to the bank.
\end{abstract}

Keywords: Social Responsibility, Internal Social Responsibility, Regulatory Symmetry, Commercial Banks, Qatar.

\section{Introduction}

Among the things that caused uproar and great vocal in the scientific and academic circles are the social role of the organization, and the extent of its awareness of its environment, as opinions and attitudes of social responsibility of the organizations varied. All levels of society, including some who see them as social units, and therefore it is important to play an increasing social role in their environment (Al-Tadbasa, 2015). It has become more interactive and responsive in its performance area than in the past, as the social organization's response requires it to carry out responsible actions towards its human resources and the components of its external environment in order to anticipate the social performance of society, including social responsibility in general and towards its human 
INTERNATIONAL JOURNAL OF ACADEMIC RESEARCH IN BUSINESS AND SOCIAL SCIENCES Vol. 10, No. 5, May, 2020, E-ISSN: 2222-6990 @ 2020 HRMARS

resources in particular (Hussein, 2012) as it is considered The human resource is an essential pillar upon which organizations depend to achieve success, and whatever progress and development the organization has achieved in its internal performance, but it may fall prey to failure as a result of inappropriate actions towards its human resources, which indicates that the survival and continuation or deterioration of the organization Extinction is linked entirely efficient human resources and the policy pursued in dealing with it and how to motivate the required tasks efficiently and effectively performance (Abu Tayeh 2012;Al- Saffar \&obeidat, 2020).

The business environment is witnessing a lot of events and developments at the present time, and the accompanying negative phenomena and effects that formed a dilemma and a major crisis that have become obligatory for organizations to confront and confront them, which made organizational symmetry a necessary and urgent matter that must be achieved (Al-Masry and Aga, 2018) Organizational symmetry has its roots rooted in many ideas and areas which it implicitly used as Islamic thought, or outwardly as psychological and political thought. On the level of Islamic thought, the Islamic call was obligatory for every Muslim individual to comply with the laws and teachings of the Islamic religion and to adopt his goals and values and make it part of himself and unify it with his personal goals, so he considers "symmetry" one of the pillars of its basic rules (Al-Saud and AlSarayrah, 2009), but In terms of psychological thought, this thought is considered the first to explicitly and explicitly address the term "symmetry", as it was used for the first time by the psychologist (Freud) in one of his theories related to psychological analysis, as a term indicating the emotional connection of an individual with another (Al-Shammari, 2017) On the level of political thought, this term was inspired by reason Political researcher (Lasswell) thought and used it in his political theory through which he sought to discover the link between personal motives and integration with public figures, power and various issues, and he expressed that state of integration with the term "symmetry", which he meant as "an individual union with another individual or A specific group, thing, or idea "(Murabit, 2015). As for administrative thought, organizational symmetry has emerged as a result of the development of administrative theories, and their different interest in the symmetry of human resources, which can be refuted into two categories: classic administrative theories, and human administrative theories (Ghannam, 2016).

The importance of the study emerges from the importance of the topics covered and the information related to internal social responsibility and organizational similarity, as well as its importance in the limited studies, especially Arabic that touched on internal social responsibility, and it is considered the first study within the limits of the researcher's science, which examines the role of internal social responsibility in Organizational symmetry, which constitutes a new addition to the Arab library, and makes it the nucleus of other similar studies, as its importance is evident in its contribution to informing Qatar commercial banks of the importance of their role and social responsibility and identifying the most important factors that $T$ in achieving organizational symmetry and thus the Qatar commercial banks directed towards providing the necessary and appropriate efforts.

The Qatar commercial banks provide many services that are characterized by high quality, as the performance of these banks is closely related to the employees in them, as organizations and banks suffer from a misunderstanding by the employees of their goals and values, and the inability to link its goals to the goals of the bank, which reflects negatively on His loyalty and affiliation with the bank, and consequently, may affect the provision of poor banking products and services, and there are many factors that affect, negatively or positively, the organizational similarity in the bank, including internal social responsibility, which is one of the factors that raise the level of performance of 
INTERNATIONAL JOURNAL OF ACADEMIC RESEARCH IN BUSINESS AND SOCIAL SCIENCES

Vol. 10, No. 5, May, 2020, E-ISSN: 2222-6990 @ 2020 HRMARS

organizations in general $\mathrm{M}$ and the banks in particular, and based on the above, the problem of the study is trying to answer the following main question: What is the role of internal social responsibility represented by (training and development, diversity in the work environment, and the balance between work and private life) in achieving organizational symmetry for workers, for example B (organizational citizenship, organizational commitment, and organizational loyalty)?

\section{Internal Social Responsibility}

In order for organizations to achieve their status as a good citizen, they must do their utmost to achieve benefits for all stakeholders, society and the environment in general, and not all of their interest be limited to achieving the interests of owners, and social responsibility also includes achieving effective participation in social and educational activities and programs, and commitment to conservation On the environment and its protection, in addition to working in terms of the principles of accountability and transparency (Araba and Bin Daoudia, 2012), and the issue of social responsibility is one of the topics that were focused on at the present time, organizations have extracted from research and studies Which took place over the years and which was confirmed by the practical reality of the organizations that adopted and applied the concept of social responsibility that its activities and operations have an impact on the souls of the community that it deals with, as well as realized that the image that society draws in its mind about the organization and its activities and works is an important and essential element in supporting Its ability to achieve its goals (Sharfman \& Fernando, 2008), organizations are one of the main pillars of achieving social progress and prosperity, and organizations' involvement in many economic, social and environmental problems has placed them in the face off With its obligations and responsibility, it was imposed on it to correct the course of its behavior and behavior (Kanji \& Chopra, 2010), and the fact that financial institutions in general and banks in particular are like other organizations in that they are not considered charitable organizations, but rather for-profit organizations whose main goals are to generate and maximize returns (Abbasi et al., 2012), and as it is considered one of the sustainable organizations considering that it is one of its characteristics to work on achieving economic development in addition to achieving social and environmental development (Al-Hakim, 2014), it was necessary to draw its attention towards its social responsibilities and direct it towards work according to the meanings that her message carries, it reflects her role in caring for community and work on the development and access to his satisfaction(Al-Da'abseh, et al., 2018; Al-Qudah et al., 2020 ).

The Dutch Economic and Social Council defined social responsibility as a concept based on two basic dimensions, the first: the necessity of activating the role of organizations in the progress and development of society in the economic, social and environmental fields, second: achieving a balance between society and all parties associated with relationships and interests with the organization, by including this term within the mission and vision of the organization, its philosophy, culture and the goals it seeks to achieve (Ven van de \&Graafland, 2006), Al-Jinai and Abu Hadi (2018) defined it as a set of economic and social activities and processes that organizations are obligated to perform towards all parties

Associated with relationships with clients, workers, and dealers on the one hand, and toward the society that belongs to him and his environment on the other hand. Weber (2008) believes that organizations 'commitment to social responsibility towards all parties associated with relationships with them reflects positively on the work environment, as it contributes to achieving interaction with them, provides a stimulating environment for cooperation and joint action, enhances its positive 
image in society, and increases the level of confidence in the organization This leads to maximizing their ability to confront future events and crises that they may be exposed to.

Khan \& Majid (2013) also believes that the organizations commitment to work according to social responsibility contributes to raising their level of performance and helps them achieve their financial goals, as this commitment generates she has motivation andit embraces the continuous improvement in its activities and operations, achieving quality in the products and services it provides, and enhances its ability to exploit opportunities, and gives it a high skill in addressing the obstacles that hinder its course of work, and Al-Ghalia (2017) adds to the above, that the organizations commitment to social responsibility motivates them to attracting the human cadres that are characterized by the highest levels of efficiency and skill, and maximizing the capabilities and capabilities of its human resources, and increasing their loyalty and affiliation, which leads to increasing the level of their productivity higher and helping them achieve their economic and social goals, and in this regard, Belal (2008) has demonstrated that the utilization of associations to authorities here social adds to the safeguarding of the earth and the insurance of their normal assets and their assets and improvement, and add to boosting the size of the monetary increases and speculation exercises and tasks completed by the state, likewise finds that interface social obligation to the ideas of straightforwardness and change adds to lessening the predominance of debasement in its different structures (financial, administrative, and the politician), both Al-Ghalibi and Al-Amri (2010) posit that the associations' utilization of their social duty prompts accomplishing social equity, improving the personal satisfaction in all fields and at all levels, and adds to the combination of bonds and social reliance between its various gatherings, hence accomplishing strength in the public eye. The specialists concurred on the three elements of inside social obligation of associations, spoke to in, preparing and improvement, the harmony between work prerequisites and private life, and assorted variety in the workplace,( Welford, 2004; Abbass and Altarawneh, 2012 ; Ali et al, 2010 ; AlZyoud, 2013).

\section{Training and Development}

The human component who appreciates the most significant levels of capability, skill, experience, and training is viewed as the fundamental mainstay of its predominance and achievement, and a basic component in raising the degree of its exhibition and improving its capacity to contend, and hence, the associations have directed their concentration toward accomplishing the ideal interest in their HR taking numerous strategies and methodology to accomplish this. The most noticeable of which is the dependence on training frameworks and projects, given its job in improving logical abilities and capacities (Saxaf, 2017 ; Obeidat and Otibi, 2015), training is a lot of techniques, strategies, strategies, and methodology that add to the turn of events and improvement of information, skills, and practices of the human component and invigorates his scholarly and mental abilities and abilities to accomplish individual and hierarchical objectives.

Simultaneously, it is a sorted out and arranged strategy to expand the result of laborers from the data, information, and skills that add to improving and building up their exhibition, the ovaries and the stock (2012), and plans to prepare as a successful technique for training, a significant way to increment and augment profitability, a genuine interest in HR, and a key factor in accomplishing Development to accomplish proficiency and adequacy in execution, and to help the individual working in finishing occupations and undertakings to the furthest reaches, diminishing mistakes and deviations at work, expanding the devotion and connection of working people and raising their spirit, 
INTERNATIONAL JOURNAL OF ACADEMIC RESEARCH IN BUSINESS AND SOCIAL SCIENCES

Vol. 10, No. 5, May, 2020, E-ISSN: 2222-6990 @ 2020 HRMARS

building up their skills and capacities and picking up the information being developed R. In the field of work (Al-Sharia, 2014; obeidat, 2019).

\section{Diversity in the Work Environment}

Diversity in the work environment is viewed as a characteristic and normal issue in associations in its different divisions, sizes, exercises, and activities, because of the signature appended to it, and got from its relationship with the human component, which is one of the qualities of the association exuding from the variety and diversity of its social parts, which drives them to make a beneficial profitable ability To make its objectives and progress and increase upper hands by exploiting the capacities and possibilities of its HR, raising their resolve, and drawing in individuals with capabilities and skills (Aigare et al., 2011). Diversity in the work environment shows the variety of examples, qualities, and attributes of the HR working in the association, Jad Al-Rab (2010), so Vashant (2012) characterized it as the change and human and social distinction in the workforce.

In terms of gender, age, origin, race, culture, language, religion, physical and physical condition, in addition to opinions, ideas and attitudes, which contribute to establishing the principle of fairness among working individuals, and achieving efficiency and effectiveness of the organization. He also defined that the work environment includes different elements and components related to the human element in terms of ages, genders, experiences, educational and social levels, etc. (alkaemah, 2016), and the importance of diversity in the work environment is evident in that it leads to improving its competitive position, building a positive mental image of it, and gaining it the ability To grow and maximize its market value, and to achieve organizational integration and coordination for the human elements working in various businesses and at all administrative and organizational levels and assume administrative and functional responsibilities and burdens (Samara, 2017), and the importance of diversity in the work environment comes to improving the world. Human relationships, achieving organizational flexibility, taking advantage of the strengths of human resources, gaining the ability to creativity and innovation, finding solutions to different situations and crises, responding to events and changes in the work environment and adapting to them, and providing a work environment that stimulates cooperation and joint action, which reflects positively on Productivity and efficiency in achieving performance (Chawawa, 2014).

\section{Balancing Work and Private Life}

The business environment is seeing occasions and changes portrayed by their assortment, quickening, and diversity of their belongings, notwithstanding the extraordinary rivalry between their associations(Al-Omari, et al., 2020; AL-Hajri \& Obeidat, 2019). The associations thought that the most ideal approach to stand up to these occasions is to utilize their HR as far as using their energies and abilities and guiding them towards accomplishing (Aljawarneh \& Atan, 2018; ).

Its vital objectives, and pushing them towards improving the association's capacity to stand up to emergencies and difficulties that assail it, and with the goal for associations to accomplish this, they needed to follow working strategies and methodology that legitimately influence the individual existence of the human component and his capacity to adjust work and his private life (Tariq et al. 2012). the associations center around upgrading the capacity of the human component to accomplish that spending limit came out of the job that the last plays in accomplishing quality in the angles and everyday issues and work simultaneously, so the harmony among work and private life is a procedure planned for accomplishing incorporation and stream between close to home needs and Work 
requests (Gureney, 2009). Melanie (2012) characterizes it as a strategy that consolidates the necessities and prerequisites identified with work and those identified with individual life. Accomplishing a harmony among work and private life is identified with numerous components, which can be categorized into (Shah, 2014): Organizational factors: It is a group of characteristics and features related to the work environment. In terms of organizational culture, work requirements and how it is performed, periods of time, the nature of the organizational structure, the salary system, incentives and rewards followed by the organization, as well as personal (individual) factors: It is a set of characteristics and features related to the working individual in terms of his work orientation, handling method, and a degree E potential, personal and demographic qualities, and the achievement of the balance between work and private life back positive results on both the organization and the individual worker alike. For the organization, see Yasbk (2012) that the application of the balance between work and private life procedures facilitates the process of polarization.

The organization is for those with expertise, competencies, and skills from working individuals, keeping them, and reducing employee turnover rates, and thus reducing the costs incurred by them, Isamu \& Toshiyuki (2012) believes that it contributes to achieving progress and growth for organizations and increasing the size of their profits and returns, because it is working to increase its production as a result of its contribution In providing an adequate work environment by reducing the pressure of work and the number of hours, it also contributes to increasing the rate of employee loyalty and affiliation to the organization, and thus enhancing its ability to achieve its goals and strategies (Al-Omari, et al., 2018). As for the working person, Broers (2012) believes that it increases the rate of commitment $\mathrm{Ml}$ working time, it pays to the bulk of exploiting its potential and abilities and skills and possess the motivation towards the improvement and development, and the breed has a sense of satisfaction and job security and stability, and adds (Shah, 2014) as a catalyst for the success of individuals in their work, and to improve their living standards and social and family relationships.

\section{Organizational Symmetry}

Organizational symmetry was defined as a dynamic and active process whereby individuals embrace organizational values and goals and link them to their personal values and goals (Al-Ghazali and AlAbadi, 2014). Al-Otaibi (2016) characterized it as organizational conduct that speaks to the sentiment of the individual working in his having a place with the association where he works and its association with it mentally and socially. The significance of organizational symmetry lies in the quality of how much the association influences its HR and its capacity to give an invigorating environment and help in accomplishing its objectives, as associations have understood that accomplishing similarity and congruity among them and their HR would add to its prosperity, prevalence, and progression, and accomplish positive outcomes coming about because of the ownership of its individuals For sentiments of fulfillment (Ghannam, 2016), and the significance of organizational symmetry is exhibited by the significant and fundamental job it plays.

In the association, which is spoken to by affecting the open enthusiasm on the individual intrigue when settling on choices identified with accomplishing the objectives of the association, building up a guarantee to work and hurrying towards improving the degree of execution and lessening the inconsistencies and clashes that happen in the environment of the association's an inside environment and adding to building a positive mental picture of the association in the public eye and 
upgrading its abilities Competitiveness (Al-Zoubi, 2013), and its significance likewise shows up in the acknowledgment of people working for the procedures of modernization and change that are in the interest of the organization, increasing their loyalty and affiliation with them, activating cooperation and teamwork, building successful relationships between individuals and uniting their efforts towards Realizing the goals and promoting the principle of collective success and accomplishing business efficiently and highly effectively (Al-Ghazali and Al-Khuzai, 2016). Al-Otaibi (2016) believes that the importance of symmetry lies through the goals that he seeks to achieve, which contribute to achieving the interests of individuals and the organization in which they work, and the most prominent of those goals are Working to increase commitment and regularity in work, achieving interaction and harmony among individuals working in the organization, and enhancing feelings of job satisfaction and conviction in work and thus achieving efficiency and effectiveness in performing business, improving the organization's position and competitive position by highlighting its competitive strengths, and accepting modernization and development easily and change that lead to the achievement of goals and interests,

Organizational symmetry is one of the forms of social symmetry, where organizations in various forms and types seek to strengthen the bonds of association and integration of their human elements with the message and vision that they adopt, and the goals they seek to achieve, where organizational symmetry leads to the organization retaining its human cadres and reducing their dropout and facilitating the process of attracting human cadres that It has the highest levels of experience, competence and skill, in addition to achieving social stability for working individuals (Al-Shammari, 2017), and to achieve the development of organizational symmetry among the members of the organization, the organization must work to meet the needs and requirements of thousands Adding and satisfying workers, fulfilling the obligations of the organization towards its members in terms of providing security and job stability, and adopting policies and strategies that contribute to building a balanced career behavior among working individuals, and motivating them to follow positive behavioral patterns, as well as giving them opportunities to achieve their own goals, in addition to enhancing confidence Between management and working individuals, and their participation in making and taking decisions, which gives them a sense of their importance and therefore their dedication to achieving the goals and interests of the organization (Jamil, 2016).

\section{Organizational Citizenship}

Organizational citizenship behavior is related to the human resource, which represents the organization's most valuable and important resource. Organizational citizenship was defined as a set of behaviors that are not included in job description cards, and are not subject to the foundations and rules for granting incentives, rewards, and promotions followed by the organization (Polat, 2009). And Mansour (2014) as an unusual behavior which is not considered a formal business requirement to maximize the efficiency of the organization. Matsushita (2015) defined it as behavior directed towards achieving the highest degree of organizational effectiveness that does not lead to material or moral returns. Achieving this type of behavior would contribute to enhancing the organization's ability to achieve its goals, improve its overall performance, and build communication and interaction channels between Management and individuals working in the various departments and administrative and organizational units (Najm and Karim, 2014). It also leads to achieving compatibility and harmony in work, raising morale among human cadres, achieving job stability, increasing the satisfaction of all individuals associated with relationships with the organization, and 
raising the degree of job satisfaction with Thousands The number of workers (Al-Raqqad and Abu Deya, 2012), and despite the importance of organizational citizenship behavior, there are many limitations that impede its exercise, including (Noah, 2013): such as the lack of freedom to express opinions and ideas, and the lack of participation of individuals working in the process of making Decisions and decisions, the unit of pressures faced by the working individual at work and the increase thereof, the absence of organizational justice, which reflects negatively on the motivation of the working individuals to exercise additional positive roles, and adopts a leadership style that is not motivating and encouraging an additional positive role.

\section{Organizational Commitment}

The subject of organizational commitment won the consideration of numerous scholars and worried about issues of organization management, as a result of its immediate constructive outcomes influencing people and associations, it prompts expanded steadfastness and connection of working people and the development of amicable and shared workgroups in information and encounters, which adds to accomplishing greatness and redesigning the exhibition of associations, It evades the numerous weights of going home and the low degree of inspiration towards it

What's more, a commitment to it (Lambert, 2016), and accordingly guaranteeing its endurance and progression, and the continuation of its endeavors towards accomplishing its objectives, and this intrigue has brought about structure numerous ideas that explain the expected importance of organizational commitment, including what Joo and Shim (2010) knows is the connection of the working individual the objectives and qualities on which the association is based, paying little mind to the material advantages accomplished by the association. The significance of organizational commitment lies in the way that it is viewed as a compelling component for integrating individuals working in the organization, achieving job stability, increasing their loyalty and affiliation, an important factor to increase their growth and maximize their productivity, and an essential indicator of efficiency Its performance (Barqoun and Darnouni, 2014), and for the organization to achieve that importance, it must strive to develop organizational commitment and develop it among its human cadres, by focusing on a set of factors, including what is related to the working individual, such as demographic factors in terms of gender, age, social status, and factors Personality in terms of his personal characteristics, capabilities, potentials, level of culture, nature of his expectations and degree of his affiliation with the organization (Zarrouqi, 2015). Some of them are related to the internal and organizational environment in terms of degree of independence, participation in decision-making, commitment to feedback, clarity of goals and degree of understanding. Ha absorbed by the personnel, and the pattern followed in the supervisory organization, including what is related to the external environment in terms of labor market conditions, and provide alternative employment opportunities and economic situation of the state (Kadiresan et al., 2015). Despite the importance that organizations achieve as a result of achieving the organizational commitment of working individuals, there are many obstacles that prevent them from achieving that commitment, the most prominent of which are (Hilles, 2012): Departments' indifference to the role played by convincing working people of the importance of roles They write down in the organization, the absence of clear and specific foundations in recruitment processes, the low sense of job stability and the ownership of individuals working for feelings of concern towards the organization, the absence of justice in granting incentives, rewards and promotions, and the inefficiency and effectiveness of their systems and rules. 
INTERNATIONAL JOURNAL OF ACADEMIC RESEARCH IN BUSINESS AND SOCIAL SCIENCES Vol. 10, No. 5, May, 2020, E-ISSN: 2222-6990 @ 2020 HRMARS

\section{Organizational Loyalty}

Organizational loyalty expresses the positive trends shown by the working factor towards the organization to achieve compatibility and harmony between it and the organization, and is considered one of the most important requirements needed to achieve effective performance and to accomplish the work as desired, something that obligated organizations to exert their utmost efforts to achieve it and to maintain, support and develop it, to ensure Its survival, growth, and persistence (Abboudi, 2008), and many researchers and thinkers have addressed the issue of organizational loyalty and lent it special importance, as he defined it (Porter, 1974), as the strength of the interaction and harmony of the individual with the organization in which he operates and the degree of his association with it, and that an individual who has faith, Jochanan explained that the desire of the organization to harness most of its energies, capabilities and capabilities in the interest of the organization, stay in it, and accept its values and goals, and expresses a strong desire to continue as a member in it, with a high degree of organizational loyalty towards the organization. He indicated that it is the result of the interaction of three basic elements, namely: congruence: which means the degree of individual acceptance of the values and goals of the organization in which he operates and the conviction that it reflects his goals and self-values, and effective participation and satisfaction: which means the individual's involvement in his activities and roles that he performs within a For an organization, sensing the importance of what he does, satisfaction with his work in the organization, loyalty and loyalty: which means the belonging of the working individual to the organization in which he works and considering it part of himself, and the desire to keep his work in all cases (Al-Rawashid, 2008). Organizational loyalty is of great importance, as it affects many administrative and organizational behaviors and phenomena that are embodied in the desire to stay in the job, commitment to work, and the level of performance and achievement (Al-Azzawi and Abbas, 2010). In order for this importance to be achieved, the management of organizations must work to increase and maximize the loyalty of its members And its development, which is achieved through satisfying their needs and requirements, clearly and accurately setting goals and roles, achieving job satisfaction, providing an appropriate work environment, and working to enrich jobs and tasks (Derry, 2011), and despite that importance, there are many The Obstacles that limit the ability of organizations to achieve organizational loyalty and development, including those that relate to the personality of the working individual in terms of his capabilities, capabilities and level of culture, the degree of his responsibilities, and the nature of his expectations and desires, including what is related to the internal environment of the organization in terms of the nature of work, policies, procedures and organizational strategies And among them, what is related to the external environment in terms of the labor market situation, economic conditions and opportunities for selection (Hamed, 2017; Malkawi et al, 2017).

\section{Research Methodology}

Hypotheses development and research mode

The researcher has adopted the descriptive and analytical approach to describe the role of internal social responsibility in achieving organizational symmetry in Qatar commercial banks. Where a questionnaire was designed to measure the independent variables represented by the dimensions of internal social responsibility, and the dependent variables represented by the dimensions of organizational symmetry, and to find the relationship between the variables of the study, analysis 
INTERNATIONAL JOURNAL OF ACADEMIC RESEARCH IN BUSINESS AND SOCIAL SCIENCES Vol. 10, No. 5, May, 2020, E-ISSN: 2222-6990 @ 2020 HRMARS

and interpretation in order to reach generalizations with a meaning that increases and enriches the balance of knowledge on the subject.

$\mathrm{H} 1$ : There is a positive effect of Internal Social Responsibility on organizational citizenship

$\mathrm{H} 2$ : There is a positive effect of Internal Social Responsibility on organizational commitment.

H3: There is a positive effect of Internal Social Responsibility on organizational loyalty

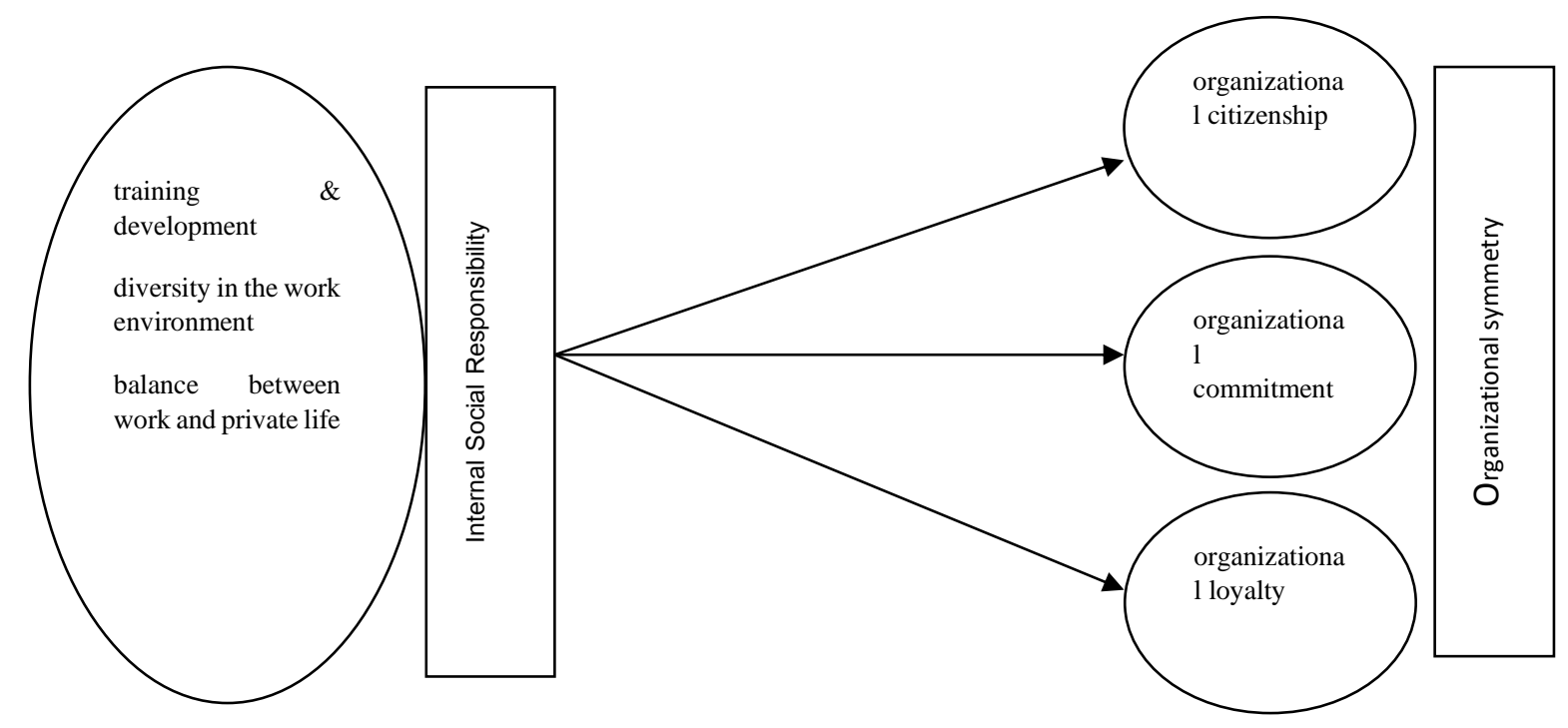

\section{Society and Study Sample}

The study population included all 7 Qatar commercial banks. (5) Banks (Gulf Bank Qatar, National Bank, Commercial Bank, Qatar National Bank, Doha Bank) were chosen to form the study sample, which is one of the oldest and largest banks in terms of the number of employees. The inspection unit included the workers at all administrative levels, where they numbered (9025) employees, and the researcher distributed (372) questionnaires, and retrieved (340) questionnaires, (30) questionnaires were excluded because they were not completed and were not valid for statistical analysis, so that the researcher has (310) A questionnaire valid for analysis, with a recovery rate of (83.3\%), which is statistically acceptable.

It was found from the sample of the study that males constitute (54.5\%), while females constitute (45.5\%) of the sample, and this may be due to the reluctance of women to work in the banking sector for the length of official working hours. The age group (less than 25 years) has formed the largest percentage of the sample, with a rate of (56.1\%), and this indicates the trend of banks to attract the youth to work with them to diversify and multiply their tasks and jobs, which requires a large number of human cadres in various Administrative levels, especially lower levels, to provide customer services. We note that holders of the (Bachelor's) degree have formed the largest percentage of the study sample, which amounted to (62.6\%), and this corresponds to the general trend in the public and private sectors, which requires the employment of workers who hold a first university degree (Bachelor's) as a minimum. As for the members of the sample from the experience category (less than 5 years), they formed the largest percentage, at a rate (47.4\%), and this corresponds to the distribution of the sample according to the variable of the age group. We also note that the category (employee) has formed the largest percentage of members of the study sample, which amounted to (79.4\%), while the category (department manager) and the category (department head) formed the 
INTERNATIONAL JOURNAL OF ACADEMIC RESEARCH IN BUSINESS AND SOCIAL SCIENCES Vol. 10, No. 5, May, 2020, E-ISSN: 2222-6990 ㄷ 2020 HRMARS

smallest percentage of members of the study sample, which reached $(5.1 \%, 15.5) \%)$, Respectively, and this corresponds to the administrative pyramid for the distribution of workers in the organizational structures of organizations, where the number increases as we go towards the base of the administrative pyramid.

Table 1. Distribution of the sample population according to demographic variables

\begin{tabular}{|c|c|c|c|}
\hline Variable & Category & Repetition & Percentage \\
\hline \multirow{3}{*}{ Gender } & Male & 169 & 54.5 \\
\hline & female & 141 & 45.5 \\
\hline & Total & 310 & 100 \\
\hline \multirow{6}{*}{ age } & Less than 25 & 174 & 56.1 \\
\hline & From 25 - less than 35 & 106 & 34.2 \\
\hline & From 35 - less than 45 & 24 & 7.8 \\
\hline & From 45 - less than 55 & 4 & 1.3 \\
\hline & 55 and over & 2 & 0.6 \\
\hline & Total & 310 & 100 \\
\hline \multirow{5}{*}{ Qualification } & Intermediate diploma or less & 80 & 25.8 \\
\hline & BA & 194 & 62.6 \\
\hline & M.A. & 24 & 7.8 \\
\hline & PhD & 12 & 3.8 \\
\hline & Total & 310 & 100 \\
\hline \multirow{6}{*}{$\begin{array}{c}\text { Years of } \\
\text { experience }\end{array}$} & Less than 5 years & 147 & 47.4 \\
\hline & From 5 - less than 10 years & 131 & 42.2 \\
\hline & $\begin{array}{c}\text { From } 10 \text { - less than } 15 \text { years } \\
\text { old }\end{array}$ & 8 & 2.6 \\
\hline & $\begin{array}{c}\text { From } 15 \text { - less than } 20 \text { years } \\
\text { old }\end{array}$ & 16 & 5.2 \\
\hline & $\begin{array}{c}\text { From } 20 \text { - less than } 25 \text { years } \\
\text { old }\end{array}$ & 8 & 2.6 \\
\hline & Total & 310 & 100 \\
\hline \multirow{4}{*}{ Position } & Manager & 16 & 5.1 \\
\hline & Head of Department & 48 & 15.5 \\
\hline & Employee & 246 & 79.4 \\
\hline & Total & 310 & 100 \\
\hline
\end{tabular}

\section{Research Method}

The researcher designed a questionnaire consisting of the following parts; Part One: This part contains demographic data for respondents, namely: gender, age, educational qualification, years of work experience, and job title. As for the second part: This part relates to internal social responsibility, and includes the following dimensions: Training and development, diversity in the work environment, and the balance between work and private life. As for the third part: This part relates to organizational symmetry, and includes the following dimensions: organizational citizenship, organizational commitment, and organizational loyalty, and each variable was measured using a Likert scale pt) 
INTERNATIONAL JOURNAL OF ACADEMIC RESEARCH IN BUSINESS AND SOCIAL SCIENCES Vol. 10, No. 5, May, 2020, E-ISSN: 2222-6990 @ 2020 HRMARS

which consists of (1-5) degrees where (5) means strongly agree, (4) means agree, (3) means neutral, (2) means disagree, and (1) means strongly disagree.

The apparent honesty of the questionnaire was tested by presenting it to arbitrators with experience and specialization from academic professors, in order to express an opinion regarding it in terms of its suitability to collect data related to the study, and its clarity, coherence and coherence, or any other notes that they deem appropriate in relation to correction, deletion and according to what The arbitrator sees it. The arbitrators' observations and suggestions were taken into consideration, and the questionnaire review and auditing process was considered by the arbitrators, their observations and suggestions were taken, in addition to the amendments referred to by them as a test of the apparent honesty of the tool, and accordingly the study tool is valid for measuring what it was designed for. The stability of the instrument used to measure the variables it contains was also tested using the Cronbach Alpha Coefficient test, where the result of the scale is statistically acceptable if the value of the Cronbach alpha is greater than (0.60) (Sekaran, 2013), and the closer the value approaches (100\%) This indicates higher stability degrees for the study tool, and given the data in the following table, the coherence factor coherence alpha was measured for the variables of the study and for its dimensions and for the study tool as a whole, to find out the consistency of the answers; we notice from Table (3) that the values of the coefficient of The internal consistency of the Cronbach alpha for the study instrument paragraphs ranged (0.933-0.978), in addition to that the alpha value for all paragraphs has reached(0.982), and therefore all values are greater than (0.60). This is an indication of the consistency between the paragraphs of the study instrument, the reliability and reliability of the study tool for conducting statistical analysis.

Table 2. Internal consistency coefficient values

\begin{tabular}{|l|l|l|}
\hline$\#$ & \multicolumn{1}{|c|}{ Variables } & \multicolumn{1}{c|}{ Cronbach Alpha } \\
\hline 1 & 0.978 & 0.978 \\
\hline 2 & 0.933 & 0.933 \\
\hline 3 & 0.975 & 0.975 \\
\hline \multicolumn{2}{|c|}{ Internal social responsibility } & 0.976 \\
\hline 4 & 0.948 & 0.948 \\
\hline 5 & 0.945 & 0.945 \\
\hline 6 & 0.920 & 0.920 \\
\hline \multicolumn{2}{|c|}{ Organizational symmetry } & 0.965 \\
\hline \multicolumn{2}{|c|}{ All paragraphs } & 0.982 \\
\hline
\end{tabular}

\section{Research Results}

\section{Descriptive Statistics}

In order to study the effect of internal social responsibility on organizational symmetry, descriptive analysis was used to describe respondents' positions on questionnaires related to independent and dependent variables. According to the Likert quintet scale for the alternatives of the answer to each paragraph, through the relative importance, and was determined according to the following mathematical formula, the upper limit of the alternative - the minimum of the alternative / number of levels $(5-1 / 3=1.33)$ where the level is considered low if the arithmetic average of 1.00 - Less than 2.33. The alternative is considered moderate if the mean is from 2.33 - to less than 3.66. The alternative is considered high if the mean is from 3.66 - up to 5.00 . 
INTERNATIONAL JOURNAL OF ACADEMIC RESEARCH IN BUSINESS AND SOCIAL SCIENCES Vol. 10, No. 5, May, 2020, E-ISSN: 2222-6990 @ 2020 HRMARS

Table 3. Computational averages and standard deviations of study dimensions

\begin{tabular}{|c|c|c|c|c|}
\hline \# & Variables & Mean & SD & Level \\
\hline 1 & training and development & 3.779 & 0.910 & High \\
\hline 2 & $\begin{array}{l}\text { Diversity in the work } \\
\text { environment }\end{array}$ & 3.726 & 0.694 & High \\
\hline 3 & $\begin{array}{l}\text { Balancing work and private } \\
\text { life }\end{array}$ & 3.690 & 0.977 & High \\
\hline \multicolumn{2}{|c|}{$\begin{array}{c}\text { Dimensions of internal social } \\
\text { responsibility }\end{array}$} & 3.732 & 3.732 & 0.772 \\
\hline 1 & Organizational citizenship & 3.761 & 0.760 & High \\
\hline 2 & $\begin{array}{c}\text { Organizational } \\
\text { commitment }\end{array}$ & 3.991 & 0.689 & High \\
\hline 3 & Organizational loyalty & 3.902 & 0.669 & High \\
\hline \multicolumn{2}{|c|}{$\begin{array}{c}\text { Dimensions of Organizational } \\
\text { symmetry }\end{array}$} & 3.885 & 3.885 & 0.630 \\
\hline
\end{tabular}

We note from Table No. (3) that the overall average of the dimensions of internal social responsibility in terms of relative importance is high, and after (training and development) came first with high relative importance and this indicates an interest by banks in identifying the training needs and requirements of employees on an ongoing basis, and training Its employees have different skills that are compatible with work requirements, motivating them to apply educational outcomes from training on the ground, followed by after (diversity in the work environment), and this indicates that the Qatar commercial banks are not gender-biased (male or female) or a specific race when recruiting and recruiting Human cadres $E$, and their assumption of leadership and career positions and tasks, as it does not consider their belongings when motivating them to highlight their skills, abilities and capabilities. And came after (the balance between work and private life) in the third place, and this indicates the management of Qatar commercial banks to achieve a balance between work and private life, by providing adequate facilities for employees to care for their children and their families, and giving them emergency leave and paid private leave. In general, the previous dimensions appeared of high relative importance. This indicates the interest of Qatar commercial banks in performing their internal social responsibility and putting the needs and requirements of their employees at the highest level of their priorities and interests, and this stems from its view of the human element, which it considers the most important and richest resource and the key to its success and progress, which was reflected in its role in raising the level of performance of its human resources, and improving Their standard of living, and their psychological and social stability.

As we note from Table No. (3), the results of the analysis of the study tool showed an increase in the relative importance of organizational symmetry in Qatar commercial banks, and after (organizational commitment) ranked first, and this indicates that the bank employees accept advice and guidance from others positively and without complaining, and they show commitment and compliance In the internal system of the bank, with or without supervision, the Commercial Banks Department also encourages its employees to cooperate and work together, and to initiate assistance and assistance to each other. Followed by (organizational loyalty), and this It refers to the employees of Qatar Commercial Banks making a great effort in achieving the goals of the bank and helping them succeed, and they show a great deal of interest in its future, and are ready to perform any tasks entrusted to 
them to ensure the maintenance and continuation of their current work. And it came in third place after (organizational citizenship), and this indicates a commitment by Qatar commercial bank employees to the system of legislation (laws, regulations, instructions, and regulations) and the policies determined by the bank, as they accept orders and directives issued by officials and higher departments, and they abide What is required of them, and in general the previous dimensions appeared of high relative importance. This indicates the interest of Qatar commercial banks in achieving compatibility between their goals and values and those goals and values adopted by their human resources, which would generate feelings of loyalty and belonging in the hearts of employees and increase their commitment to them, which would lead them to exert their maximum energy and capabilities and use them to achieve the goals and interests of the bank.

\section{Hypotheses Testing Results}

In this part of the study we review the hypothesis test, where it was subjected to Multiple Linear Regression analysis. As the results of Table (4) indicate that there is a positive relationship between (internal social responsibilities) and (organizational citizenship). It turns out that the value of the determination coefficient $\left(R^{2}=0.633\right)$, and this means that (internal social responsibility) has explained $(63.3 \%)$ of the variance in (organizational citizenship), with other factors remaining constant. It also shows that the value of $(F)$ has reached $(175.702)$ at the confidence level $(\mathrm{Sig}=0,000)$ and this confirms the significance of the regression, while the table of transactions showed that the value of $B$ at the distance (training and development) has reached $(0.255)$ and that the value of $t$ has (5.172), With a significance level $(\mathrm{Sig}=0.000)$ which is less than 0.05 , which indicates that the effect of this dimension is significant. $B$ appeared at a dimension (diversity in the work environment) with a value of (0.227) and that the value of thas a value of (3.603), and a level of significance (Sig $=0.000)$ which is less than 0.05 , which indicates that the effect of this dimension is significant. $B$ also appeared at a dimension (the balance between work and private life) with a value of $(0.290)$ and the value of $t$ (7.508), and the level of significance ( $\mathrm{Sig}=0.000$ ) which is less than 0.05 , which indicates that the effect of this dimension is significant.

Table 4. Results of the test of the impact of internal social responsibility on organizational citizenship

\begin{tabular}{|c|c|c|c|c|c|c|c|c|c|c|c|c|}
\hline \multirow{2}{*}{ DV } & \multicolumn{4}{|c|}{ Model Summary } & \multicolumn{3}{|c|}{ ANOVA } & \multicolumn{5}{|c|}{ Coefficients } \\
\hline & $\mathrm{R}$ & $R^{2}$ & $\operatorname{Adj} R^{2}$ & $\begin{array}{l}\text { standar } \\
\text { d error }\end{array}$ & $\mathrm{F}$ & $P$ & Df & $\begin{array}{l}\text { Independent } \\
\text { variables }\end{array}$ & B & SE & $\mathrm{T}$ & $P$ \\
\hline \multirow{4}{*}{$Q C$} & \multirow[t]{4}{*}{0.795} & \multirow[t]{4}{*}{0.633} & \multirow[t]{4}{*}{0.629} & \multirow[t]{4}{*}{0.463} & \multirow[t]{4}{*}{175.702} & \multirow[t]{4}{*}{0.000} & \multirow[t]{4}{*}{3} & $\begin{array}{l}\text { training and } \\
\text { development }\end{array}$ & 0.255 & 0.049 & 5.172 & 0.000 \\
\hline & & & & & & & & $\begin{array}{l}\text { Diversity in the } \\
\text { work } \\
\text { environment }\end{array}$ & 0.227 & 0.063 & 3.603 & 0.000 \\
\hline & & & & & & & & $\begin{array}{l}\text { Balancing work } \\
\text { and private life }\end{array}$ & 0.290 & 0.039 & 7.508 & 0.000 \\
\hline & & & & & & & & $\begin{array}{l}\text { Gradient } \\
\text { constant }\end{array}$ & 0.882 & 0.144 & 6.131 & 0.000 \\
\hline
\end{tabular}

* The effect is statistically significant at $(\alpha \leq 0.05)$ 
INTERNATIONAL JOURNAL OF ACADEMIC RESEARCH IN BUSINESS AND SOCIAL SCIENCES Vol. 10, No. 5, May, 2020, E-ISSN: 2222-6990 @ 2020 HRMARS

The results of Table (5) also indicate that there is a positive relationship between (internal social responsibilities) and (organizational commitment). It turns out that the value of the determination coefficient ( $R 2=0.488$ ), and this means that (internal social responsibility) has explained $(48.8 \%)$ of the variance in (organizational commitment), with other factors remaining constant. It also turns out that the value of $(F)$ has reached (97.219) at a confidence level ( $\mathrm{Sig}=0,000)$ and this confirms the significance of the slope, while the table of transactions showed that the value of $B$ at the distance (training and development) has reached (0.184) and that the value of thas (3.490), With a significance level (Sig $=0.001)$ which is less than 0.05 , indicating that the effect of this dimension is significant. B appeared at the dimension (diversity in the work environment) with a value of (0.315) and that the value of his $t$ is (4.669), and the level of significance (Sig $=0.000$ ) which is less than 0.05 , which indicates that the effect of this dimension is significant. $B$ also appeared at a dimension (the balance between work and private life) with a value of $(0.151)$ and the value of $t(3,658)$, and at the level of significance $(\mathrm{Sig}=0.000$ ) which is less than 0.05 , which indicates that the effect of this dimension is significant.

Table 5. Results of testing the effect of internal social responsibility on organizational commitment

\begin{tabular}{|c|c|c|c|c|c|c|c|c|c|c|c|c|}
\hline \multirow[b]{2}{*}{ DV } & \multicolumn{4}{|c|}{ Model Summary } & \multicolumn{3}{|c|}{ ANOVA } & \multicolumn{5}{|l|}{ Coefficients } \\
\hline & $\mathrm{R}$ & $\mathrm{R}^{2}$ & $\operatorname{Adj} R^{2}$ & SE & $\mathrm{F}$ & $\begin{array}{l}\text { Sig } \\
(F)\end{array}$ & Df & $\begin{array}{l}\text { Independent } \\
\text { variables }\end{array}$ & B & SE & $\mathrm{T}$ & $p$ \\
\hline \multirow{4}{*}{$\mathrm{OC}$} & \multirow[t]{4}{*}{$\begin{array}{l}0.69 \\
9\end{array}$} & \multirow[t]{4}{*}{$\begin{array}{l}0.48 \\
8\end{array}$} & \multirow[t]{4}{*}{0.483} & \multirow[t]{4}{*}{$\begin{array}{l}0.49 \\
6\end{array}$} & \multirow[t]{4}{*}{$\begin{array}{l}97.21 \\
9\end{array}$} & \multirow[t]{4}{*}{$\begin{array}{l}0.00 \\
0\end{array}$} & \multirow[t]{4}{*}{3} & $\begin{array}{l}\text { training and } \\
\text { development }\end{array}$ & $\begin{array}{l}0.18 \\
4\end{array}$ & $\begin{array}{l}0.05 \\
3\end{array}$ & $\begin{array}{l}3.49 \\
0\end{array}$ & $\begin{array}{l}0.00 \\
1\end{array}$ \\
\hline & & & & & & & & $\begin{array}{l}\text { Diversity in } \\
\text { the work } \\
\text { environment }\end{array}$ & $\begin{array}{l}0.31 \\
5\end{array}$ & $\begin{array}{l}0.06 \\
7\end{array}$ & $\begin{array}{l}4.66 \\
9\end{array}$ & $\begin{array}{l}0.00 \\
0\end{array}$ \\
\hline & & & & & & & & $\begin{array}{l}\text { Balancing } \\
\text { work and } \\
\text { private life }\end{array}$ & $\begin{array}{l}0.15 \\
1\end{array}$ & $\begin{array}{l}0.04 \\
1\end{array}$ & $\begin{array}{l}3.65 \\
8\end{array}$ & $\begin{array}{l}0.00 \\
0\end{array}$ \\
\hline & & & & & & & & $\begin{array}{l}\text { Gradient } \\
\text { constant }\end{array}$ & $\begin{array}{l}1.56 \\
2\end{array}$ & $\begin{array}{l}0.15 \\
7\end{array}$ & $\begin{array}{l}10.1 \\
30\end{array}$ & $\begin{array}{l}0.00 \\
0\end{array}$ \\
\hline
\end{tabular}

* The effect is statistically significant at $(\alpha \leq 0.05)$

The results of Table (6) indicate that there is a positive relationship between (internal social responsibilities) and (organizational loyalty). It turns out that the value of the coefficient of determination $\left(R^{2}=0.448\right)$, and this means that (internal social responsibility) has explained $(44.8 \%)$ of the variance in (organizational loyalty), with other factors remaining constant. It also turns out that the value of $(F)$ has reached (82.738) at a confidence level (Sig $=0,000)$ and this confirms the significance of the regression, while the table of transactions showed that the value of $B$ at the distance (training and development) has reached $(0.220)$ and that the value of $t$ has $(4.122)$, With a significance level $(\mathrm{Sig}=0.000)$ which is less than 0.05 , which indicates that the effect of this dimension is significant. B appeared at a dimension (diversity in the work environment) with a value of $(0.150)$ and that the value of $t$ has a value of $(2.202)$, and a level of significance ( $\mathrm{Sig}=0.028$ ) which is less than 0.05 , which indicates that the effect of this dimension is significant. $\mathrm{B}$ also appeared at the dimension 
INTERNATIONAL JOURNAL OF ACADEMIC RESEARCH IN BUSINESS AND SOCIAL SCIENCES Vol. 10, No. 5, May, 2020, E-ISSN: 2222-6990 @ 2020 HRMARS

(work-private balance) with a value of (0.199) and the value of $t(4.760)$, and the level of significance (Sig $=0.000)$ which is less than 0.05 , which indicates that the effect of this dimension is significant.

Table 6. Results of the test of the impact of internal social responsibility on organizational commitment

\begin{tabular}{|c|c|c|c|c|c|c|c|c|c|c|c|c|}
\hline \multirow[b]{2}{*}{ DV } & \multicolumn{4}{|c|}{ Model Summary } & \multicolumn{3}{|c|}{ ANOVA } & \multicolumn{5}{|c|}{ Coefficients } \\
\hline & $\mathrm{R}$ & $\mathrm{R}^{2}$ & Adj $R^{2}$ & $\begin{array}{l}\text { stan } \\
\text { dard } \\
\text { error }\end{array}$ & $F$ & Sig F & Df & IV & B & SE & $\mathrm{T}$ & $p$ \\
\hline \multirow{4}{*}{ OL } & \multirow[t]{4}{*}{$\begin{array}{l}0.66 \\
9\end{array}$} & \multirow[t]{4}{*}{$\begin{array}{l}0.44 \\
8\end{array}$} & \multirow[t]{4}{*}{0.442} & \multirow[t]{4}{*}{$\begin{array}{l}0.50 \\
0\end{array}$} & \multirow[t]{4}{*}{$\begin{array}{l}82.73 \\
8\end{array}$} & \multirow[t]{4}{*}{$\begin{array}{l}0.00 \\
0\end{array}$} & \multirow[t]{4}{*}{3} & $\begin{array}{l}\text { training and } \\
\text { development }\end{array}$ & $\begin{array}{l}0.22 \\
0\end{array}$ & $\begin{array}{l}0.05 \\
3\end{array}$ & $\begin{array}{l}4.12 \\
2\end{array}$ & $\begin{array}{l}0.00 \\
0\end{array}$ \\
\hline & & & & & & & & $\begin{array}{l}\text { Diversity in } \\
\text { the work } \\
\text { environment }\end{array}$ & $\begin{array}{l}0.15 \\
0\end{array}$ & $\begin{array}{l}0.06 \\
8\end{array}$ & $\begin{array}{l}2.20 \\
2\end{array}$ & $\begin{array}{l}0.02 \\
8\end{array}$ \\
\hline & & & & & & & & $\begin{array}{l}\text { Balancing } \\
\text { work and } \\
\text { private life }\end{array}$ & $\begin{array}{l}0.19 \\
9\end{array}$ & $\begin{array}{l}0.04 \\
2\end{array}$ & $\begin{array}{l}4.76 \\
0\end{array}$ & $\begin{array}{l}0.00 \\
0\end{array}$ \\
\hline & & & & & & & & & $\begin{array}{l}1.78 \\
2\end{array}$ & $\begin{array}{l}0.15 \\
5\end{array}$ & $\begin{array}{l}11.4 \\
6\end{array}$ & $\begin{array}{l}0.00 \\
0\end{array}$ \\
\hline
\end{tabular}

* The effect is statistically significant at $(\alpha \leq 0.05)$

\section{Discussion and Conclusion}

The results of the hypothesis test showed an effect of internal social responsibility in its dimensions combined on achieving both organizational citizenship, organizational commitment, and organizational loyalty, where the moral impact appeared at all dimensions, and this indicates the importance of the dimensions of internal social responsibility in achieving organizational parity. The results of this study were consistent with the results of the study (Education, 2015), which concluded that there is a positive relationship between training and development, the balance between work and private life, and diversity in the work environment and between the behavior of organizational citizenship and organizational justice, and the study (Al-Hassan, 2014) indicated Until the adoption of the idea of social responsibility by the company improves its performance, also came the results of the study (Al-Hayasat et al., 2015), which concluded that there is an effect of internal responsibility on institutional performance, where he indicated that the interest of organizations in their responsibility towards their human resources is one of the forms of their commitment to achieve their Social responsibilities Cleared him, reflecting the organization's contribution to the upgrading of the level of performance of its human resources and improve their standard of living, and the achievement of social and psychological stability to them. And that the perceptions of each employee about corporate social responsibility are positively linked with the special organizational commitment (Kimet al, 2016) and that a systematic method of training on organizational citizenship behavior shows positive results on the performance of workers in the dimensions of cooperative work within the group and increase the motivation to work and increase the financial profits and job satisfaction (Scott, Phillip \& Nathan, 2011) He referred (Ferrell and Ferrell, 2005); (Eamets and Mõtsmess, 2010) that internal social responsibility has a strong impact on job satisfaction through rewards, promoting 
personal development and work-life balance, and ensuring occupational health and safety, which is reflected in the overall performance of the organization. Likewise, the institution's commitment to its responsibility towards the employee is greater in determining the extent of his loyalty to it (Iqbal, Tufail \& Lodhi, 2015). The suitability of the work environment is highly correlated with employee satisfaction (Mafini \& Dlodlo, 2014).

\section{Implications}

This study came to discuss the effect of inner social obligation in accomplishing organizational symmetry, where the study model was based on the dependence on past examinations that are pertinent to the theme, and in the wake of checking on the past writing, it very well may be noticed that comparative investigations have not been directed in the Qatar banking division, where this study was introduced Many hypothetical commitments. Social duty speaks to one of the types of the association's commitment to its duties towards society and its persistent communication in fulfilling its needs, fulfilling its wants and its commitment to accomplishing feasible advancement in the entirety of its structures (financial, social and environmental). As for organizational symmetry, the human element possesses feelings of loyalty, belonging to the organization in which he operates and commitment to it as a result of what he perceives as harmony and congruence between his goals and values and those that he adopts and which the organization seeks to achieve, which drives him towards exerting his maximum energies and capabilities and employing them in achieving the goals and interests of the organization.

The results of this study showed that internal social responsibility can have an effect in achieving organizational symmetry in Qatar commercial banks. The results of this study are expected to contribute to encouraging all banks operating in Qatar, in addition to other profit organizations to the need to continue to adhere to and maintain its internal social responsibility, because of its positive impact on the performance of its employees and the achievement of their goals and objectives of the bank, and the need to adhere to its responsibility towards workers, And workers with special needs by providing jobs commensurate with their situation, and providing them with adequate support so that they can fully perform their duties. As well as seeking to provide awarenessraising blogs and bulletins to inform their employees of their rights related to achieving compatibility between work and private life, and to provide flexible work policies such as part-time work, in addition to facilitating the process of practicing their educational activities such as providing effective training programs that empower workers and develop their performance, and granting them leave to study to develop the level Educational to them.

\section{References}

Abbasi, T., Kausar, A., Ashiq, H., Inam, H., Nasar, H., \& Amjad, R. (2012). Corporate Social Responsibility Disclosure: A Comparison Between Islamic and Conventional Financial Institutions in Bahawalpur Region.Thelslamia University of Bahawalpur, Pakistan Research Journal of Finance and Accounting, 3 (3).

Abbass, A., \& Altarawneh, I. (2012). Corporate Social Responsibility and Employee Engagement in Jordan. International Journal of Business and Management, 7 (16) 89 - 105.

Abu Tayeh, B. (2012). The impact of organizational justice on citizen organizational behavior in the centers of government ministries in Jordan. Journal of the Islamic University for Economic and Administrative Studies, 20 (2), pp. 145-186. 
INTERNATIONAL JOURNAL OF ACADEMIC RESEARCH IN BUSINESS AND SOCIAL SCIENCES

Vol. 10, No. 5, May, 2020, E-ISSN: 2222-6990 @ 2020 HRMARS

Abudi, M. Z. (2008). Administrative organization and its basic principles. Jordan Amman: Osama Publishing and Distribution House.

Aigare, A., Koyumdzhieva, T., \& Thomas, P. L. (2011). Diversity Management in Higher Education Institutions: Key Motivators.

Al- Saffar, N. A. G., and Obeidat, A. M. (2020) The effect of total quality management practices on employee performance: The moderating role of knowledge sharing, Management Science Letters, 10 (2020) 77-90

Al Saud, R., and Al Sarayrah, K. A. (2009). The organizational similarity of the faculty members in the official Jordanian universities and its reasons for their job performance. Journal of Educational Sciences, ( 36) 186-204.

Al taamsah, S. A. K. (2015). The relationship between corporate social responsibility and organizational citizenship behavior: organizational justice as an intermediary variable, a field study of eligible industrial zone firms in Jordan. Unpublished doctoral dissertation, Sudan University of Science and Technology, Khartoum, Sudan.

Al-Azzawi, N., Abdullah, A. H. J. (2010). Strategic functions in human resource management. Jordan, Amman: Al Yazouri Scientific Publishing and Distribution House.

Albdour, A., \& Altarawneh, I. (2014). Employee Engagement and Organizational Commitment: Evidence from Jordan. International Journal of Business, 19 (2), 192 - 212.

Al-Da'abseh, T., Aljawarneh, N., \& Shwiyat, Z. (2018). Marketing Mix Startegies and Its Impact on Organizational Performance Efficiency in the Jordanian Company for Investment and SupplySafeway: An Empirical Study. Invention Journal of Research Technology in Engineering \& Management, 2(2), 14-23.

AL-Hajri, Khaled, M. A., \& Obeidat, A. M. (2019) The Impact Psychological Empowerment in Achieving Job Satisfaction at the Police College, Qatar, International Journal of Business and Management. 14( 9)1-14.

Al-Hakim, M. (2014), "Social Responsibility from the Point of View of Dealers with Islamic Jordanian Banks", Al-Balqa Journal for Research and Studies, 17( 2), 15-56.

Al-Hassan, B. B. M. (2014). The role of social responsibility in improving the performance of the organization: a case study of the Batfel Unit and Batna Unit. Unpublished Master Thesis, University of Mohamed Khader, Biskra, Algeria.

Al-Jawarneh, N. M. S. (2016). Case study: Business management school the Turkish republic of north Cyprus and how strategic thinking and planning can improve the performance of the organization to maintain stable between competitors. Invention Journal of Research Technology in Engineering \& Management (IJRTEM), 1(5), 64-72.

Aljawarneh, N. M. S., \& Atan, T. (2018). Linking Tolerance to Workplace Incivility, Service Innovative, Knowledge Hiding, and Job Search Behavior: The Mediating Role of Employee Cynicism. Negotiation and Conflict Management Research, 11(4), 298-320.

Aljawarneh, N., \& Al-Omari, Z. (2018). The Role of Enterprise Resource Planning Systems ERP in Improving Customer Relationship Management CRM: An Empirical Study of Safeway Company of Jordan. International Journal of Business and Management, 13(8), 86-100.

Alkaemah, Al-Q. (2016). Organizational strategies and practices for managing cultural diversity. Journal of Social Wisdom, 3 (6), 99-111. 
INTERNATIONAL JOURNAL OF ACADEMIC RESEARCH IN BUSINESS AND SOCIAL SCIENCES

Vol. 10, No. 5, May, 2020, E-ISSN: 2222-6990 @ 2020 HRMARS

Al-Omari, Z. S., Aljawarneh, N., Davut, S., \& Salah, A. (2018). The Impact of Marketing Mix Elements on Forming Mental Images about Islamic Banks in Jordan: An Empirical Study. OFFICIAL, 12, 54.

Al-Omari, Z., Alomari, K., \&Aljawarneh, N. (2020). The role of empowerment in improving internal process, customer satisfaction, learning and growth. Management Science Letters, 10(4), 841848.

Al-Otaibi, T. bin K. (2016) organizational similarity among the faculty members of Taif University. Journal of Educational and Psychological Sciences, 9 (3), 705-762.

Al-Qudah, S., Obeidat, A. M., Shrouf, H., and Abusweilem, M. A. (2020). The impact of strategic human resources planning on the organizational performance of public shareholding companies in Jordan. Problems and Perspectives in Management, 18(1), 219-230.

Al-Raqqad, H., and Abu Dayyah, A. (2012). Emotional intelligence among academic leaders in public Jordanian universities and its relationship to the behavior of organizational citizenship among faculty members. Journal of the Islamic University for Educational and Psychological Studies, 20 (2), pp. 737-763.

Al-Rawashed, S. K. (2008). School decision-making, a sense of security and organizational loyalty. Jordan, Amman: Dar Al-Hamid for Publishing and Distribution,.

Al-Shammari, F. O. (2017). The degree to which middle school principals in the Farwaniya educational area practice organizational justice and its relationship to the organizational similarity of teachers. Unpublished Master Thesis, Al-Bayt University, Mafraq, Jordan.

Al-Zayoud, A. N. T. (2013). The social responsibility of banks operating in Jordan. Journal of Management Science Studies, 40 (1), 75-87, University of Jordan, Amman, Jordan.

Al-Zoubi, K. (2013). The degree to which private school principals in Amman practice the dimensions of transformational leadership and its relationship to organizational similarity from the teachers' point of view. Unpublished Master Thesis, Middle East University, Amman, Jordan.

Araba, R., Bin Dawoudia, and Wahiba. (2012). Corporate social responsibility and its role in development: presenting the experiences of some international companies. International Forum on: Business Organizations and Social Responsibility, February 14-15, University of Bechar, Algeria.

Belal U. M. (2008). Three Dimensional Aspects of Corporate Social Responsibility, Daffodil International University. Journal of Business and Economics, 3 (1), 201-213.

Broers, M. (2012). Work - Life Balance: Important for Business. JAG, 9 (3347), Office of Fair and Safe Work Queensland, Queensland, Australia.

Chawawa, M. (2014). Diversity Management Practices in Higher Education: Evidence from Private Higher Education Institutions in Botswana. Journal of Education and Practice, 5 (18), 31-46.

Derry, Z. M. (2011). organizational behavior. Jordan, Amman: Al Masarra for Publishing and Distribution,.

El Ghalia, M. A. (2017). The impact of social responsibility on competitiveness in Islamic banks. Unpublished doctoral dissertation, International Islamic Science University, Amman,

Ghannam, A. A. R. (2016). The effect of organizational symmetry on the organizational commitment of government employees in the city of Irbid. Unpublished Master Thesis, Yarmouk University, Irbid, Amman.

Graafland, J., \& Van de Ven, B. (2006). Strategic and moral motivation for corporate social responsibility. Journal of Corporate Citizenship, (22), 111-123. 
INTERNATIONAL JOURNAL OF ACADEMIC RESEARCH IN BUSINESS AND SOCIAL SCIENCES

Vol. 10, No. 5, May, 2020, E-ISSN: 2222-6990 @ 2020 HRMARS

Sarah, G. (2009). Gender Work - Life Balance and Health amongst Women and Men in Administrative, Manual and Technical Jobs in a Single Organization: A Qualitative Study. Unpublished Doctor Thesis, University of Glasgow, Scotland.

Hamed, H. M. S. M. (2017). The effect of incentives on achieving organizational loyalty: a case study of the Khartoum State Water Authority. Unpublished Master Thesis, University of Al-Neelain, Khartoum, Sudan.

Saqer, H. (2012). The role of change management in enhancing organizational commitment among workers: a case study on the Gaza municipality. Unpublished Master Thesis, Islamic University, Gaza, Palestine.

LaithSaadallah, H. (2012). Social responsibility towards workers and its reflection on work ethics: a study of the opinions of a sample of employees of some hospitals in Mosul. Journal of Future Research, 3 (38), 1-33.

Iqbal, A., Tufail, S., \& Lodhi, N. (2015). Employee Loyalty and Organizational Commitment in Pakistani Organizations. Global Journal of Human Resource Management, 3 (1), 1-11.

Yamamoto, I., \& Matsuura, T. (2012). Effect of Work - Life Balance Practices on Firm Productivity: Evidence from Japanese Firm - Level - Panel Data. RIETI Discussion Paper Series 12 - E - 079, Keio University.

Rab, J. A., Muhammad, S. (2010). International Business Management: Fundamentals, International Strategies, Applications. 2nd floor, Cairo, Egypt.

Jameel, A. K. A. (2016). Training and development of human resources. Jordan, Amman: Jandariyah Publishing and Distribution,.

Joo, B., \& Shim, J. (2010). Psychological Empowerment and Organizational Commitment: the Moderating Effect of Organizational Learning Culture. Human Resource Development International, 13 (4), 425 - 441.

Kadiresan, V., Selamat, M., Selladurai, S., Ramendran, C. H., \& Mohamed, M. (2015). Performance Appraisal and Training and Development of Human Resource Management Practices (HRM) ON Organizational Commitment and Turnover Intention. Asian Social Science, 11 (24), 162 176.

Kanji, G. K., \& Chopra, P. K. (2010). Corporate Social Responsibility in a Global Economy.Total Quality Management, 21 (2), $119-143$.

Khan, M., and Majid, A. (2013). The Impact of Corporate Social Responsibility on Profitability and Market Share: A Case of Cement Industry of Pakistan. Academic Journal of Management Sciences, 2 (1).

Kim, J. S., Song, H. J., \& Lee, C. K. (2016). Effects of corporate social responsibility and internal marketing on organizational commitment and turnover intentions. International Journal of Hospitality Management, 55, 25-32.

Lambert, J. (2016). Cultural Diversity as a Mechanism for Innovation: Workplace Diversity and the Absorptive Capacity Framework. Journal of Organizational Cultural, Communication and Conflict, 20 (1), 68 - 77.

Maamri, H., and Mansour, Bin Z. (2014). Organizational citizenship behavior as a tool for organizational effectiveness in modern organizations. Journal of Humanities and Social Sciences, 1 (14), 43-54. 
INTERNATIONAL JOURNAL OF ACADEMIC RESEARCH IN BUSINESS AND SOCIAL SCIENCES

Vol. 10, No. 5, May, 2020, E-ISSN: 2222-6990 @ 2020 HRMARS

Mafini, C., \& Dlodlo, N. (2014). The linkage between work-related factors, employee satisfaction and organisational commitment: Insights from public health professionals. SA Journal of Human Resource Management, 12(1), 12.

Malkawi, D. N. M., Baniata, D. M. I., \& Obeidat, A. M. (2017). The Impact of E-Government Applications on Decision-Making Effectiveness: Case Study at Jordanian Ministry of InteriorJordan. International Review of Management and Business Research, 6(1), 172.

Matsushita, H. (2015). The Study of Organizational Citizenship Behavior with a Focus on the Complexity of Motives. Business Studies Journal, 7 (2), 101 - 111.

Melanie, A. (2012). An Empirical Investigation into the Impact of Work - Life Balance Practices on Employees and Employers. Unpublished Master Thesis, University of Stellenbosch, South Africa.

Mobaideen, O. M., and Jaradat, O. M. (2012). Performance-oriented management training. Egypt, Cairo: Arab Administrative Development Organization.

Murabit, S. O. (2015). The organizational dimensions of symmetry and their relationship to the level of psychological pressure among public health midwives: a field study on public health institutions in Biskra. Unpublished Master Thesis, University of Mohamed Khader, Biskra, Algeria.

Najm, N., and Karim, K. (2014). The role of organizational confidence in enhancing the behavior of organizational citizenship: an analytical diagnostic study, the opinions of a sample of workers in the Kirkuk municipality directorate. Journal of Literature Al-Farahidi, (2), 337-369.

Noah, A. (2013). The effect of organizational support on corporate performance and organizational citizenship behavior: an applied study in industrial companies in Sahab City. Unpublished Master Thesis, Middle East University, Amman, Jordan.

Obeidat A. M., \&Otibi, G. A., (2015). The Impact of Knowledge Sharing Tools on Levels of Organizational Learning (Field Study on Jordanian Commercial Banks) Australian Journal of Basic and Applied Sciences, 9(5), 253-267.

Obeidat, A. (2019). IT Adaption with Knowledge Conversion Process (SECI)?. Management Science Letters, 9(13), 2241-2252.

Plum, Abd al-R., \& Darnouni, H. (2014). Organizational commitment: concept, dimensions and results. Journal of Human and Society Sciences, 20 (5), 225-260.

Polat, S. (2009). Organizational Citizenship Behavior (OCB) Display Levels of the Teachers at Secondary Schools According to the Perceptions of the School Administrators. Procedia Social and Behavioral Sciences, 1, 1591 - 1596.

Porter, L. W., Steers, R. M., Mowday, R. T., \& Boulian, P. V. (1974). Organizational commitment, job satisfaction, and turnover among psychiatric technicians. Journal of applied psychology, 59(5), 603.

Samara, N. S. R. (2017). The reality of diversity management and its impact on organizational culture in Palestinian universities, Gaza governorates. Unpublished Master Thesis, Islamic University, Gaza, Palestine.

Saxaf, A. (2017). The role of training in improving human resource performance. Unpublished Master Thesis, University of Mohamed Khader, Biskra, Algeria.

Scott, M., Phillip, P., \& Nathan, P. (2011). Challenge - Oriented Organizational Citizenship Behaviors and Organizational Effectiveness. Personnel Psychology, 64 (3), p. 559-592. 
INTERNATIONAL JOURNAL OF ACADEMIC RESEARCH IN BUSINESS AND SOCIAL SCIENCES

Vol. 10, No. 5, May, 2020, E-ISSN: 2222-6990 ㄷ 2020 HRMARS

Sekaran, U. \&Bougie, R. (2013), Research Methods for Business (6th ed). United Kingdom: John Wiley $\&$ Sons Ltd.

Shah, S. S. (2014). The Role of Work - Family Enrichment in Work Life Balance and Career Success: A Comparison of German and Indian Managers.

Sharfman, M. P., \& Fernando, C. S. (2008). Environmental risk management and the cost of capital. Strategic management journal, 29(6), 569-592.

Sharia, A. M. T. (2014). Management of the training process. I 1, Dar Al-Hamid for Publishing and Distribution, Amman, Jordan.

Tariq, A., Aslam, H. D., Siddique, A., \&Tanveer, A. (2012). Work - Life Balance as a Best Practice Model of Human Resource Management: A Win - Win Situation Tool for the Employees and Organizational.

Vashanti, S. P. (2012). Diversity Management Time for A New Approach in An Organization. Journal of Business and Management, 3 (3), 44-50.

Weber, M. (2008). The business case for corporate social responsibility: A company-level measurement approach for CSR. European Management Journal, 26(4), 247-261.

Welford, R. (2004). Corporate social responsibility in Europe and Asia: Critical elements and best practice. Journal of corporate citizenship, (13), 31-47.

Yasbek, P. (2012). The Business Case for Firm - Level Work - Life Balance Policies: A Review of the Literature. Wellington. 